\title{
Nasal eosinophilia induced by PAF-acether is accompanied by the release of eosinophil cationic protein
}

\author{
A. Tedeschi, N. Milazzo, A. Miadonna
}

\begin{abstract}
Nasal eosinophilia induced by PAF-acether is accompanied by the release of eosinophil cationic protein. A. Tedeschi, N. Milazzo, A. Miadonna. CERS Journals Ltd 1994.

ABSTRACT: It has been demonstrated that platelet-activating factor (PAF)-acether can induce nasal neutrophilia and eosinophilia, with a different degree of responsiveness in atopic and in nonatopic subjects. The aim of this study was to evaluate whether PAF can also induce the release of secondary mediators in the human nose.

Ten patients with allergic rhinitis and 10 normal subjects underwent nasal challenge with PAF (500 nmol), lyso-PAF (500 nmol) and saline solution. Nasal lavages were performed before and after challenge to evaluate changes in nasal cytology and release of histamine, immunoreactive leukotriene (iLT) $\mathrm{C}_{4}$ and eosinophil cationic protein (ECP).

PAF caused neutrophilia and eosinophilia, which appeared earlier in atopic than in nonatopic subjects ( $30 \mathrm{~min} v s \mathbf{~ h}$ ), and peaked $3 \mathrm{~h}$ after challenge in both groups. Lyso-PAF caused mild neutrophilia, which appeared $3 \mathrm{~h}$ after challenge in both groups; an increase in eosinophil counts was observed $3 \mathrm{~h}$ after challenge in atopic subjects, but not in nonatopic subjects. PAF insufflation caused a significant release of ECP in nasal lavage fluids $30 \mathrm{~min}$ and $3 \mathrm{~h}$ after challenge in atopic subjects, and $3 \mathrm{~h}$ after challenge in nonatopic subjects. ECP levels in the nasal lavages collected $30 \mathrm{~min}$ and $3 \mathrm{~h}$ after challenge with PAF were higher in atopic than in nonatopic subjects. Eosinophil counts correlated with ECP levels in the nasal lavages collected 30 min after PAF challenge in atopic subjects. Nasal challenge with lyso-PAF did not provoke any release of ECP. No significant increase of histamine and iLTC levels in nasal lavages was found after challenge with either PAF or lyso-PAF.

These results indicate that PAF-induced nasal eosinophilia is accompanied by ECP release, which appears earlier and is more marked in atopic than in nonatopic subjects. Eur Respir J., 1994, 7, 1445-1451.
\end{abstract}

Respiratory Allergy and Immunology Unit, Dept of Internal Medicine, University of Milan, Ospedale Maggiore Policlinico, Milan, Italy.

\author{
Correspondence: A. Miadonna \\ Pad. Granelli \\ Ospedale Maggiore Policlinico \\ Via Sforza, 35 \\ I-20122 Milan \\ Italy
}

Keywords: Eosinophil cationic protein lyso-PAF

nasal lavage

platelet-activating factor (PAF)

Received: January 251994

Accepted after revision May 191994
0The lipid mediator platelet-activating factor (PAF)acether has a broad range of biological activities, which may be important in inflammatory and allergic reactions [1]. We have investigated the possible involvement of PAF in allergic rhinitis, and have found that PAF can be released, along with its precursor/metabolite lyso-PAF, in nasal lavage fluids during the early antigen-induced reaction in patients with respiratory allergy [2]. Nasal challenge with PAF provokes nasal obstruction with an increase in nasal airway resistances [3], and nasal hyperreactivity [4, 5]. Furthermore, nasal neutrophilia and eosinophilia have been observed after challenge with PAF, with a more rapid and more marked response in atopic than in normal subjects [6]. PAF is recognized as a potent bronchoconstrictor in humans [7], but some of its effects in vivo may be mediated indirectly by the release of secondary mediators [8-11]. Cyclo-oxygenase inhibitors and thromboxane or leukotriene (LT) antagonists can modulate PAF-induced bronchoconstriction, suggesting that these substances could mediate some PAF-induced effects on respiratory airways [8, 10, 11]. Generation of leukotrienes in response to PAF stimulation has been described from perfused rabbit lung [12], perfused guinea-pig lung [13], and human neutrophils [14], and eosinophils [15]. PAF can also induce histamine release from rat kidney mast cells [16], and human basophils [17].

The aim of this study was to evaluate whether the effects of PAF on the nose are direct, or mediated by the release of secondary mediators. We have performed nasal challenge with PAF in 10 allergic subjects and 10 normal subjects. In addition, we have evaluated accompanying cytological changes and mediator release (histamine, $\mathrm{LTC}_{4}$, eosinophil cationic protein) in nasal lavage fluids.

\section{Subjects and methods}

\section{Subjects and study design}

Ten patients with allergic rhinitis ( 6 men and 4 women, aged 19-37 yrs) and 10 normal subjects (5 men and 5 women, aged 18-34 yrs) were selected for this study. Allergic rhinitis was diagnosed by clinical history and skin-prick tests. The study was performed in the winter, 
when the patients were symptom free and were not taking any medication. Informed consent was obtained from each subject prior to study. Each subject underwent nasal stimulation with PAF, lyso-PAF and saline solution, which were instilled in a blinded fashion at intervals of at least one month. Nasal lavages were performed under basal conditions and at different postchallenge times (30 min, 1, 3 and $24 \mathrm{~h}$ ), to evaluate mediator release and changes in nasal cytology. The results obtained after nasal insufflation of saline solution were used as controls.

\section{Nasal challenge and nasal lavage procedure}

PAF (1-0-hexadecyl-2-acetyl-sn-glycero-3-phosphorylcholine; Bachem, Bubendorf, Switzerland) and lysoPAF (1-0-hexadecyl-sn-glycero-3-phosphorylcholine; Bachem, Bubendorf, Switzerland) were dissolved in 100\% ethanol (final concentration 1\%) and diluted in $0.9 \% \mathrm{w} / \mathrm{v}$ $\mathrm{NaCl}$ solution containing $0.25 \% \mathrm{w} / \mathrm{v}$ serum albumin (Institut Mérieux, Lyon, France). These solutions were divided into small aliquots and frozen at $-20^{\circ} \mathrm{C}$. The solution employed for challenge was thawed just before use. PAF, lyso-PAF or saline solution were nebulized into the nose by means of a disposable metered-dose nebulizer calibrated to deliver $100 \pm 10 \mu \mathrm{l}$ per puff. The dose of $500 \mathrm{nmol}$ of PAF was chosen because we have previously observed that this could provoke nasal symptoms and changes in nasal cytology in most subjects $[3,6]$.

To evaluate changes in nasal cytology and mediator levels, nasal lavage fluids were collected using a technique described previously $[2,18]$. Briefly, $5 \mathrm{ml}$ of $0.9 \% \mathrm{w} / \mathrm{v}$ $\mathrm{NaCl}$ were instilled into each nostril. After $10 \mathrm{~s}$, the subject expelled the mixture of saline solution and mucus, which was collected in conical polypropylene tubes (Falcon, Becton Dickinson Labware, Oxnard, CA, USA). Recovery of nasal lavage fluid ranged $50-80 \%$ of the starting volume (10 $\mathrm{ml}$ for each washing). Nasal lavages were performed before and $30 \mathrm{~min}, 1,3$ and $24 \mathrm{~h}$ after nasal stimulation. Nasal lavage fluids were shaken to disperse mucus, and aliquots were collected for total cell counts, which were performed in duplicate in a Fuchs Rosenthal chamber (Firma Walter Schrenck Gmbh, Hofheim am Taunus, Germany) after staining with Turk liquid $(50 \mu \mathrm{l}$ sample and $450 \mu \mathrm{l}$ Turk liquid, prepared by Farmacia Ospedale Policlinico, Milan, Italy). Eosinophil count was performed by Randolph staining (solutions provided by Farmacia Ospedale Policlinico, Milan, Italy) [19]. The lavage samples were then centrifuged at $1,000 \times \mathrm{g}$ for $10 \mathrm{~min}$ at $4^{\circ} \mathrm{C}$. The supernatant of each sample was aspirated and the cell pellet was resuspended in $1 \mathrm{ml}$ of $0.9 \% \mathrm{NaCl}$ with $0.1 \%$ human serum albumin (HSA). Two cytospin slides for each sample were prepared $\left(100 \mu\right.$ with $2-4 \times 10^{4}$ cells per slide; centrifugation at $500 \mathrm{rpm}$ for $10 \mathrm{~min}$ in a Shandon cytocentrifuge; Shandon Southern Ltd, Runcorn, Cheshire, UK). Cytocentrifuge slides were stained by May-Grünwald Giemsa (staining solutions provided by Farmacia Ospedale Policlinico, Milan, Italy) and examined by light microscope under oil immersion. At least 200-300 cells were examined in each slide. The cells were classified as epithelial cells, neutrophils, eosinophils and mononuclear cells of unclear origin, a category that included lymphocytes and monocytes. The reader was blinded as to whether the subject had received PAF, lyso-PAF or saline solution.

\section{Mediator assays}

Histamine. Aliquots of the supernatants from nasal lavage fluids were diluted $1 / 2$ with $4 \% \mathrm{v} / \mathrm{v}$ perchloric acid, centrifuged at $2,000 \times \mathrm{g}$ for $15 \mathrm{~min}$ at $4^{\circ} \mathrm{C}$, and assayed in duplicate for histamine concentration by an automated fluorometric technique [20]. The sensitivity of this method is $1 \mathrm{ng} \cdot \mathrm{ml}^{-1}$.

$L T C_{4}$. Aliquots of the supernatants for the leukotriene assay were aspirated, decanted and extracted following the method of ANDERSON et al. [21]. The lavage supernatants were mixed with four volumes of absolute ethanol (Carlo Erba, Milan, Italy) and left at $2-8^{\circ} \mathrm{C}$ for $30 \mathrm{~min}$. The protein-rich precipitate was removed by centrifugation at $3,000 \times \mathrm{g}$ for $30 \mathrm{~min}$ at $4^{\circ} \mathrm{C}$; the ethanol supernatant was collected, decanted and then removed by rotary evaporation under vacuum. The samples were stored at $-20^{\circ} \mathrm{C}$ and then redissolved in distilled water for radioimmunoassay.

The determination of immunoreactive leukotriene $\mathrm{C}_{4}$ (iLTC ${ }_{4}$ ) was made by radioimmunoassay, using commercially available kits (Amersham, Littlechalfont, UK), performed according to the method of HAMmOND et al. [22]. The anti-LTC $\mathrm{L}_{4}$ antibody utilized in the assay crossreacts with $\mathrm{LTD}_{4}(64 \%)$ and $\mathrm{LTE}_{4}(64 \%)$. The sensitivity of the assay is $0.125 \mathrm{ng} \cdot \mathrm{ml}^{-1}$ and the intra-assay and interassay variations do not exceed $10 \%$. Every sample was assayed in duplicate and the results were expressed as ng. $\mathrm{ml}^{-1}$ lavage fluid. The results of the radioimmunological assay for iLTC $_{4}$ in nasal lavage fluids were previously validated by high performance liquid chromatography analysis [2,18], performed according to the technique of SAUTEBin et al. [23].

Eosinophil cationic protein. The concentration of the eosinophil cationic protein (ECP) was measured by radioimmunoassay, using a commercially available kit (Pharmacia, Uppsala, Sweden), which followed the method of VENGE et al. [24]. The sensitivity of the assay is 2 $\mathrm{ng} \cdot \mathrm{ml}^{-1}$ and cross-reactivity of the anti-ECP rabbit antiserum is less than $0.06 \%$ with eosinophil peroxidase.

\section{Statistical analysis}

Results were expressed as mean \pm SEM. The two-tailed Student's t-test for paired data was used to analyse the changes in cell populations and mediator levels in the nasal lavages (prechallenge values were compared with postchallenge values obtained at different times; moreover, the values obtained after PAF or lyso-PAF challenge were compared with the values obtained after insufflation of saline solution). Pearson's correlation coefficient was used to analyse the correlation between cells and mediator levels. P-values lower than 0.05 were considered significant. 


\section{Results}

Cytological changes in nasal lavage fluids after stimulation with PAF, lyso-PAF or saline solution

Total cells counts (mean \pm SEM) in prechallenge nasal lavages were $208.9 \pm 58.1 \times 10^{3}$ (range $50-675 \times 10^{3}$ ) in atopic subjects and $184.2 \pm 45.9 \times 10^{3}$, (range $34-422 \times 10^{3}$ ) in normal subjects, although the difference was not significant. Nasal stimulation with PAF provoked an increase in total cell counts in the nasal lavages collected $3 \mathrm{~h}$ after stimulation in both groups (atopic subjects $385.8 \pm 51.7 \times 10^{3}$; $\mathrm{p}<0.006$, (range 91-1,040 $\times 10^{3}$ ); nonatopic subjects $410.4 \pm 106.5 \times 10^{3} ; \mathrm{p}<0.05$ (range $\left.100-600 \times 10^{3}\right)$ ). In contrast, no significant increase in total cell counts was observed after lyso-PAF or saline insufflation. Both

a)

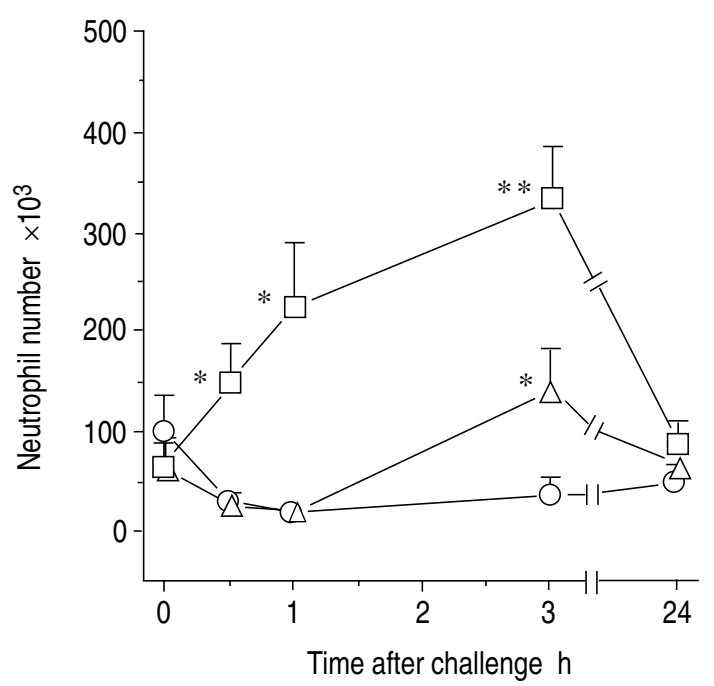

groups showed higher total cell counts after PAF challenge than after saline insufflation (atopic subjects $\mathrm{p}<0.05$ at $1 \mathrm{~h}$, and $\mathrm{p}<0.02$ at $3 \mathrm{~h}$; nonatopic subjects $\mathrm{p}<0.05$ at $1 \mathrm{~h}$, and $\mathrm{p}<0.02$ at $3 \mathrm{~h}$ ).

Epithelial cells, neutrophils and eosinophils were identified as the three main types of cells in nasal lavage fluids, and represented almost the total cell counts. Challenge with PAF induced nasal neutrophilia, which appeared after $30 \mathrm{~min}$ in atopic subjects and after $1 \mathrm{~h}$ in nonatopic subjects and peaked after $3 \mathrm{~h}$ in both groups. Milder neutrophilia was found $3 \mathrm{~h}$ after lyso-PAF challenge in both groups (fig. 1). PAF challenge also provoked eosinophilia, which was evident after $30 \mathrm{~min}$ in atopic subjects and after $3 \mathrm{~h}$ in nonatopic subjects. Increased eosinophil counts were found $3 \mathrm{~h}$ after lyso-PAF challenge in atopic subjects, but not in nonatopic subjects (fig. 2).

b)

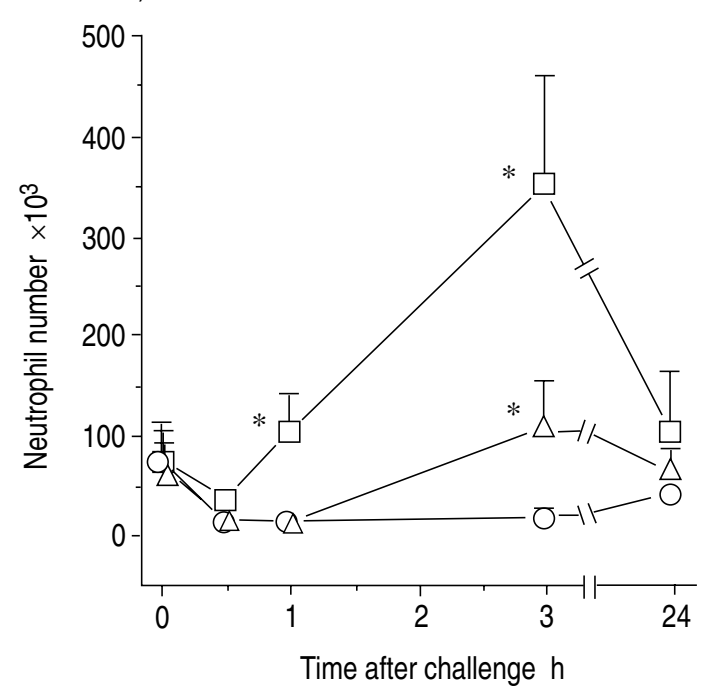

Fig. 1. - Time course of neutrophil counts in nasal lavage fluids collected after PAF $(\square, 500 \mathrm{nmol})$, lyso-PAF ( $\triangle, 500 \mathrm{nmol})$, or saline solution $(\mathrm{O}, 0.9 \% \mathrm{w} / \mathrm{v} \mathrm{NaCl}$ solution) challenge: a) in 10 atopic subjects; and b) in 10 normal subjects. Results are expressed as mean \pm sem. $* * *$ : significantly different from control value after insufflation of saline solution at $\mathrm{p}<0.05,<0.01$. PAF: platelet-activating factor.

a)

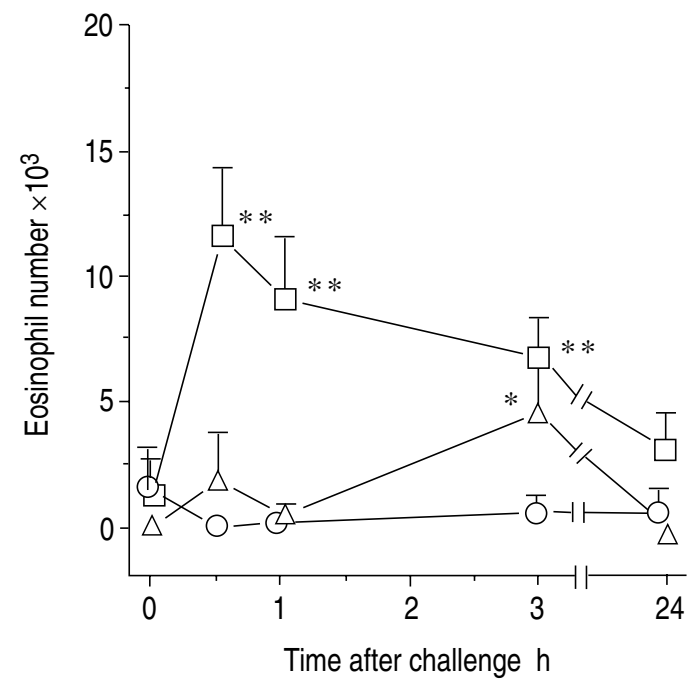

b)

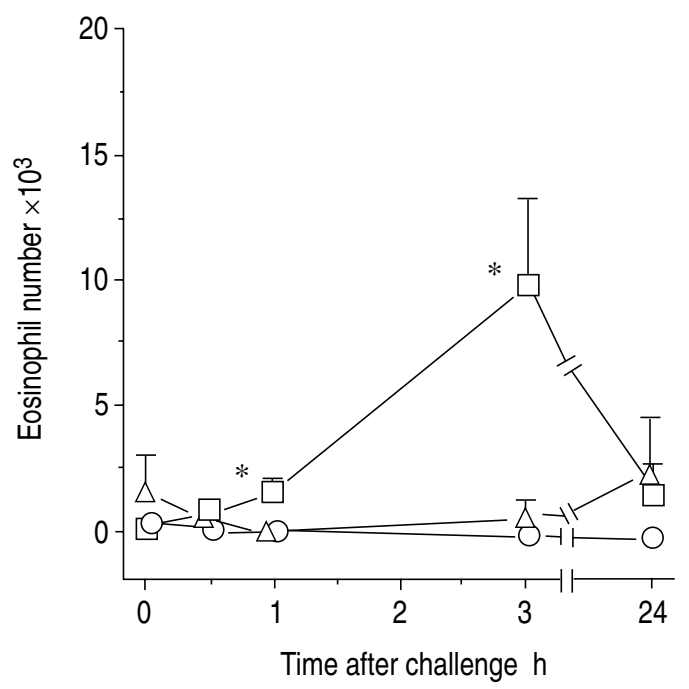

Fig. 2. - Time course of eosinophil counts in nasal lavage fluids collected after PAF ( $\square, 500 \mathrm{nmol})$, lyso-PAF ( $\Delta, 500 \mathrm{nmol})$, or saline solution challenge (O): a) in 10 atopic subjects; and b) in 10 normal subjects. Results are expressed as mean \pm sem. ***: significantly different from control value after insufflation of saline solution at $\mathrm{p}<0.05,<0.01$. PAF: platelet-activating factor. 
a)

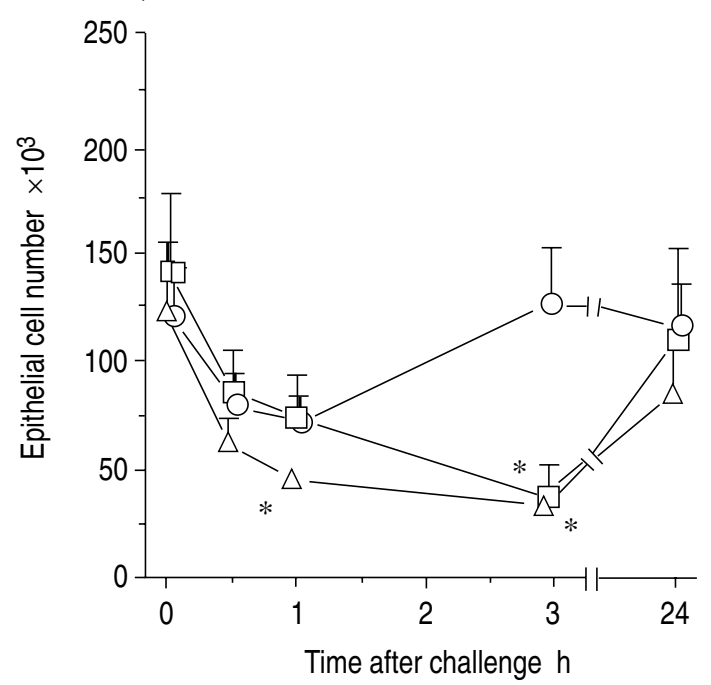

b)

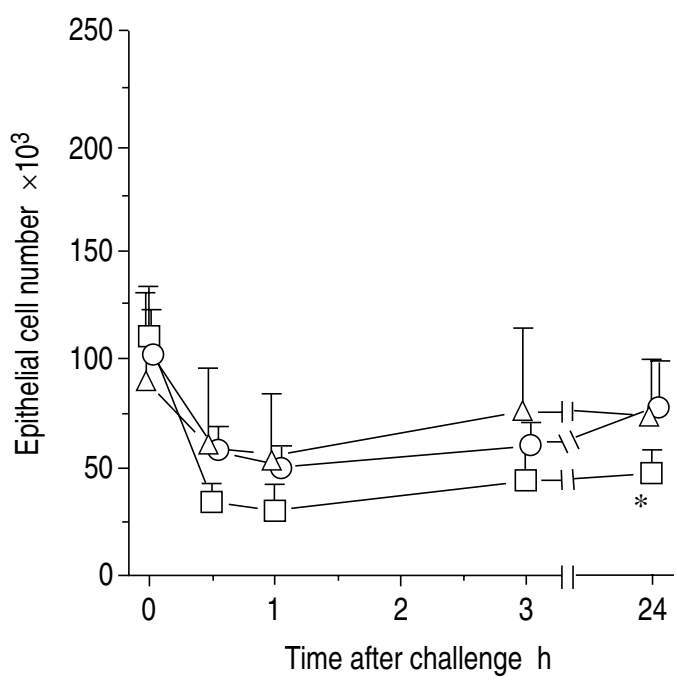

Fig. 3. - Time course of epithelial cell counts in nasal lavage fluids collected after PAF ( $\square, 500 \mathrm{nmol})$, lyso-PAF ( $\Delta, 500 \mathrm{nmol})$, or saline solution challenge $(O)$; a) in 10 atopic subjects; and b) in 10 normal subjects. Results are expressed as mean \pm SEM. *: significantly different from control value after insufflation of saline solution at $\mathrm{p}<0.05$. PAF: platelet-activating factor.

The time course of epithelial cell counts was inverse to that of neutrophils, with reduced counts in the first three hours following PAF challenge. Epithelial cell counts were also decreased $3 \mathrm{~h}$ after lyso-PAF challenge in atopic subjects (fig. 3 ).

Saline insufflation was devoid of any significant effect on cellular composition of nasal lavage fluids.

\section{Mediator levels in nasal lavage fluids}

Histamine. Histamine concentration (mean \pm SEM) in prechallenge lavages was $15.3 \pm 4.5 \mathrm{ng} \cdot \mathrm{ml}^{-1}$ (range $2-50$ $\mathrm{ng} \cdot \mathrm{ml}^{-1}$ ) in atopic subjects, and $15.4 \pm 6.1 \mathrm{ng} \cdot \mathrm{ml}^{-1}$ (range 2-66 ng. $\mathrm{ml}^{-1}$ ) in nonatopic subjects, without any significant difference between the two populations. As observed previously [2, 18], the histamine found in prechallenge conditions was not associated with any clinical symptoms. No significant changes in histamine concentration were found after PAF challenge, though a trend towards a reduction was observed in the nasal lavages collected up to $3 \mathrm{~h}$ after challenge. The time course of histamine concentration was similar after PAF, lyso-PAF or saline insufflation (table 1). Furthermore, the response was similar in both groups.

$L T C_{4}$. Low levels of $\mathrm{iLTC}_{4}$ were found in the nasal lavages collected under basal conditions (mean \pm SEM $0.40 \pm 0.11 \mathrm{ng} \cdot \mathrm{ml}^{-1}$, range $0.12-1.0 \mathrm{ng} \cdot \mathrm{ml}^{-1}$, in atopic subjects; and $0.37 \pm 0.10 \mathrm{ng} \cdot \mathrm{ml}^{-1}$, range $0.12-1.2 \mathrm{ng} \cdot \mathrm{ml}^{-1}$ in nonatopic subjects). A trend towards a reduction in $\mathrm{iLTC}_{4}$ concentration was found in the nasal lavages collected up to $3 \mathrm{~h}$ after PAF challenge, with a modest increase at $24 \mathrm{~h}$. The time course of $\mathrm{LTC}_{4}$ concentration was similar after PAF, lyso-PAF or saline insufflation (table 2).

Table 1. - Histamine levels in the nasal lavage fluids collected from 10 atopic subjects and 10 normal subjects after nasal challenge with $500 \mathrm{nmol}$ platelet-activating factor (PAF) or lyso-PAF, or saline solution

\begin{tabular}{|c|c|c|c|c|c|}
\hline & & & mine level & & \\
\hline & Baseline & $30 \mathrm{~min}$ & $1 \mathrm{~h}$ & $3 \mathrm{~h}$ & $24 \mathrm{~h}$ \\
\hline Atopic sub & & & & & \\
\hline PAF & $\begin{array}{r}15.3 \pm 4.5 \\
(2-50)\end{array}$ & $\begin{array}{r}11.8 \pm 2.6 \\
(2-30)\end{array}$ & $\begin{array}{r}9.8 \pm 1.9 \\
(2-18)\end{array}$ & $\begin{array}{r}11.7 \pm 3.1 \\
(2-31)\end{array}$ & $\begin{array}{c}13.7 \pm 3.0 \\
(2-28)\end{array}$ \\
\hline Lyso-PAF & $\begin{array}{r}18.5 \pm 7.4 \\
(2-80)\end{array}$ & $\begin{array}{r}16.4 \pm 6.3 \\
(2-60)\end{array}$ & $\begin{array}{r}14.1 \pm 6.4 \\
(2-68)\end{array}$ & $\begin{array}{r}15.6 \pm 7.2 \\
(2-76)\end{array}$ & $\begin{array}{c}18.7 \pm 8.2 \\
(2-78)\end{array}$ \\
\hline Saline & $\begin{array}{r}17.2 \pm 7.2 \\
(1-70)\end{array}$ & $\begin{array}{r}13.6 \pm 6.5 \\
(2-70)\end{array}$ & $\begin{array}{r}12.4 \pm 4.1 \\
(2-44)\end{array}$ & $\begin{array}{r}14.6 \pm 5.6 \\
(2-60)\end{array}$ & $\begin{array}{r}17.1 \pm 6.6 \\
(2-68)\end{array}$ \\
\hline Normal su & & & & & \\
\hline PAF & $\begin{array}{r}15.4 \pm 6.1 \\
(2-66)\end{array}$ & $\begin{array}{r}13.3 \pm 5.8 \\
(2-65)\end{array}$ & $\begin{array}{r}12.8 \pm 5.5 \\
(2-60)\end{array}$ & $\begin{array}{r}11.9 \pm 4.2 \\
(2-48)\end{array}$ & $\begin{array}{c}12.9 \pm 4.2 \\
(2-48)\end{array}$ \\
\hline Lyso-PAF & $\begin{array}{r}10.9 \pm 3.8 \\
(2-42)\end{array}$ & $\begin{array}{r}7.5 \pm 1.5 \\
(2-17)\end{array}$ & $\begin{array}{r}6.2 \pm 1.2 \\
(2-14)\end{array}$ & $\begin{array}{r}7.4 \pm 1.8 \\
(2-19)\end{array}$ & $\begin{array}{l}8.7 \pm 2.1 \\
(2-20)\end{array}$ \\
\hline Saline & $\begin{array}{r}11.5 \pm 3.8 \\
(2-36)\end{array}$ & $\begin{array}{r}6.1 \pm 1.5 \\
(2-15)\end{array}$ & $\begin{array}{r}4.8 \pm 1.1 \\
(2-12)\end{array}$ & $\begin{array}{r}5.5 \pm 1.3 \\
(1-14)\end{array}$ & $\begin{array}{r}9.7 \pm 2.5 \\
(2-28)\end{array}$ \\
\hline
\end{tabular}

Data are presented as mean \pm SEM and range in parentheses. 
Table 2. - $\mathrm{iLTC}_{4}$ levels in the nasal lavage fluids collected from 10 atopic subjects and 10 normal subjects after nasal challenge with $500 \mathrm{nmol}$ platelet-activating factor (PAF) or lyso-PAF, or saline solution

\begin{tabular}{|c|c|c|c|c|c|}
\hline & Baseline & $30 \mathrm{~min}$ & $\begin{array}{c}\mathrm{C}_{4} \text { levels ng } \\
1 \mathrm{~h}\end{array}$ & $3 \mathrm{~h}$ & $24 \mathrm{~h}$ \\
\hline \multicolumn{6}{|c|}{ Atopic subjects } \\
\hline PAF & $\begin{array}{c}0.40 \pm 0.11 \\
(0.12-1.00)\end{array}$ & $0.12 \pm 0.0$ & $\begin{array}{c}0.17 \pm 0.04 \\
(0.12-0.52)\end{array}$ & $\begin{array}{c}0.13 \pm 0.01 \\
(0.12-0.25)\end{array}$ & $\begin{array}{c}0.18 \pm 0.02 \\
(0.12-0.32)\end{array}$ \\
\hline Lyso-PAF & $\begin{array}{c}0.27 \pm 0.06 \\
(0.12-0.69)\end{array}$ & $\begin{array}{c}0.21 \pm 0.07 \\
(0.12-0.88)\end{array}$ & $\begin{array}{c}0.19 \pm 0.04 \\
(0.12-0.58)\end{array}$ & $\begin{array}{c}0.21 \pm 0.05 \\
(0.12-0.65)\end{array}$ & $\begin{array}{c}0.18 \pm 0.04 \\
(0.12-0.52)\end{array}$ \\
\hline Saline & $\begin{array}{c}0.20 \pm 0.04 \\
(0.12-0.54)\end{array}$ & $\begin{array}{c}0.16 \pm 0.03 \\
(0.12-0.42)\end{array}$ & $\begin{array}{c}0.14 \pm 0.01 \\
(0.12-0.28)\end{array}$ & $\begin{array}{c}0.15 \pm 0.01 \\
(0.12-0.30)\end{array}$ & $\begin{array}{c}0.15 \pm 0.02 \\
(0.12-0.33)\end{array}$ \\
\hline \multicolumn{6}{|c|}{ Normal subjects } \\
\hline PAF & $\begin{array}{c}0.37 \pm 0.10 \\
(0.12-1.20)\end{array}$ & $\begin{array}{c}0.25 \pm 0.09 \\
(0.12-1.05)\end{array}$ & $\begin{array}{c}0.12 \pm 0.0 \\
(0.12-0.12)\end{array}$ & $\begin{array}{c}0.14 \pm 0.01 \\
(0.12-0.23)\end{array}$ & $\begin{array}{c}0.21 \pm 0.006 \\
(0.12-0.80)\end{array}$ \\
\hline Lyso-PAF & $\begin{array}{c}0.16 \pm 0.02 \\
(0.12-0.36)\end{array}$ & $\begin{array}{c}0.17 \pm 0.05 \\
(0.12-0.64)\end{array}$ & $\begin{array}{l}0.12 \pm 0.0 \\
(0.12-0.12)\end{array}$ & $\begin{array}{c}0.12 \pm 0.0 \\
(0.12-0.12)\end{array}$ & $\begin{array}{c}0.19 \pm 0.02 \\
(0.12-0.40)\end{array}$ \\
\hline Saline & $\begin{array}{c}0.22 \pm 0.05 \\
(0.12-0.64)\end{array}$ & $\begin{array}{c}0.12 \pm 0.0 \\
(0.12-0.12)\end{array}$ & $\begin{array}{c}0.12 \pm 0.0 \\
(0.12-0.12)\end{array}$ & $\begin{array}{c}0.13 \pm 0.005 \\
(0.12-0.16)\end{array}$ & $\begin{array}{c}0.26 \pm 0.06 \\
(0.12-0.80)\end{array}$ \\
\hline
\end{tabular}

Table 3. - ECP levels in the nasal lavage fluids collected from 10 atopic subjects and 10 normal subjects after nasal challenge with $500 \mathrm{nmol}$ platelet-activating factor (PAF) or lyso-PAF, or saline solution

\begin{tabular}{|c|c|c|c|c|c|}
\hline & \multicolumn{5}{|c|}{ ECP levels $\mathrm{ng} \cdot \mathrm{ml}^{-1}$} \\
\hline & Baseline & $30 \mathrm{~min}$ & $1 \mathrm{~h}$ & $3 \mathrm{~h}$ & $24 \mathrm{~h}$ \\
\hline \multicolumn{6}{|c|}{ Atopic subjects } \\
\hline PAF & $\begin{array}{r}19.7 \pm 7.0 \\
(2-57)\end{array}$ & $\begin{array}{c}23.1 \pm 7.8^{* \dagger} \\
(2.6-64.9)\end{array}$ & $\begin{array}{c}14.9 \pm 4.3 \\
(2-31.8)\end{array}$ & $\begin{array}{c}24.9 \pm 6.1 * \dagger \\
(2-50)\end{array}$ & $\begin{array}{c}19.8 \pm 5.5 \\
\quad(2-47.1)\end{array}$ \\
\hline Lyso-PAF & $\begin{array}{r}17.3 \pm 5.6 \\
(2-49)\end{array}$ & $\begin{array}{l}6.1 \pm 1.9 \\
(2-20.8)\end{array}$ & $\begin{array}{l}8.9 \pm 3.8 \\
(2-33.7)\end{array}$ & $\begin{array}{l}8.5 \pm 1.9 \\
(2-19.5)\end{array}$ & $\begin{array}{c}9.8 \pm 3.8 \\
(2-40.5)\end{array}$ \\
\hline Saline & $\begin{array}{l}19.8 \pm 7.3 \\
\quad(2-52.3)\end{array}$ & $\begin{array}{c}6.3 \pm 2.2 \\
(2-19.9)\end{array}$ & $\begin{array}{c}6.7 \pm 2.8 \\
(2-28.1)\end{array}$ & $\begin{array}{l}9.7 \pm 3.8 \\
(2-39.9)\end{array}$ & $\begin{array}{l}17.2 \pm 6.8 \\
\quad(2-49.8)\end{array}$ \\
\hline \multicolumn{6}{|c|}{ Normal subjects } \\
\hline PAF & $\begin{array}{l}16.9 \pm 6.5 \\
(2.3-52.9)\end{array}$ & $\begin{array}{c}4.8 \pm 1.2 \\
(2-14.9)\end{array}$ & $\begin{array}{l}5.8 \pm 2.0 \\
(2-23.1)\end{array}$ & $\begin{array}{l}9.0 \pm 1.6^{*} \\
(4.6-23)\end{array}$ & $\begin{array}{c}12.2 \pm 2.8 \\
(2.9-32.1)\end{array}$ \\
\hline Lyso-PAF & $\begin{array}{l}14.5 \pm 4.1 \\
\quad(2-40.7)\end{array}$ & $\begin{array}{c}5.2 \pm 0.9 \\
(2-10.4)\end{array}$ & $\begin{array}{l}4.3 \pm 1.0 \\
(2-12.4)\end{array}$ & $\begin{array}{l}6.3 \pm 1.0 \\
(2.7-13.2)\end{array}$ & $\begin{array}{r}10.7 \pm 3.1 \\
(2-33)\end{array}$ \\
\hline Saline & $\begin{array}{r}13.9 \pm 3.6 \\
\quad(2-31.6)\end{array}$ & $\begin{array}{l}6.9 \pm 1.6 \\
(2-13.8)\end{array}$ & $\begin{array}{c}4.0 \pm 0.7 \\
(2-8.7)\end{array}$ & $\begin{array}{l}5.6 \pm 1.1 \\
(2-12.7)\end{array}$ & $\begin{array}{r}12.1 \pm 3.6 \\
\quad(2-37.1)\end{array}$ \\
\hline
\end{tabular}

Data are presented as mean \pm SEM and range in parentheses. *: significantly different from control value after insufflation of saline solution at $\mathrm{p}<0.05$. ${ }^{\dagger}$ : significantly different from normal (nonatopic) subjects at $\mathrm{p}<0.05$. ECP: eosinophil-derived cationic protein.

$E C P$. ECP was found in prechallenge nasal lavages in both groups (mean \pm SEM $19.7 \pm 7.1 \mathrm{ng} \cdot \mathrm{ml}^{-1}$, range $2-57$ $\mathrm{ng} \cdot \mathrm{ml}^{-1}$, in atopic subjects, and $16.9 \pm 6.5 \mathrm{ng} \cdot \mathrm{ml}^{-1}$, range 2.3-52.9 $\mathrm{ng} \cdot \mathrm{ml}^{-1}$, in nonatopic subjects, without any significant difference between the two populations). A trend towards an increase in ECP levels, when compared to basal values, was found after PAF challenge in atopic subjects, but not in nonatopic subjects (in particular, 30 min and $3 \mathrm{~h}$ after challenge). When ECP levels after PAF challenge and after saline insufflation were compared, significantly higher values were observed $30 \mathrm{~min}$ and $3 \mathrm{~h}$ following PAF challenge in atopic subjects and $3 \mathrm{~h}$ after PAF challenge in nonatopic subjects (table 3 ). Furthermore, ECP levels in the nasal lavages collected
$30 \mathrm{~min}$ and $3 \mathrm{~h}$ after challenge with PAF were higher in atopic than in nonatopic subjects $(\mathrm{p}<0.05)$. No difference was found between the ECP concentrations following lyso-PAF challenge and saline insufflation.

A significant correlation was observed between eosinophil counts and ECP concentrations in the nasal lavages collected $30 \mathrm{~min}$ after challenge with PAF in atopic subjects $(r=+0.6 ; p<0.05)$.

\section{Discussion}

These results indicate that nasal eosinophilia induced by challenge with PAF is accompanied by the release of 
ECP. This release is more rapid and more marked in atopic than in nonatopic subjects. PAF is a potent chemoattractant for eosinophils and neutrophils both in vivo and in vitro $[6,25]$. A preferential accumulation of eosinophils after intradermal injection of PAF in atopic subjects was demonstrated by HENOCQ and VARGAFTIG [26]. We have found, not only a more marked nasal eosinophilia in atopic than in nonatopic subjects following challenge with PAF, but also a more rapid response in the former than in the latter, indicating that the two populations have a different capacity to recruit inflammatory cells. In vitro PAF has the capacity to stimulate eosinophil adhesion to endothelial cells [27] and eosinophil degranulation [28], with subsequent release of preformed mediators, such as ECP and major basic protein (MBP). Our data indicate that PAF maintains the capacity to induce the release of ECP in vivo when insufflated in the nose. ECP was also found in measurable amounts in prechallenge lavages, in the absence of any clinical symptoms; these levels probably reflect the basal rate of eosinophil migration and spontaneous release of mediators. Similarly, high histamine levels have been found in nasal lavage fluid, without any relation to clinical symptoms [18].

We did not detect any significant increase in histamine levels in nasal lavage fluids after challenge with PAF. This could be due to the failure of PAF to stimulate nasal mast cells or to the release of only low amounts of histamine. Also, a slow release followed by metabolic inactivation could hamper the detection of histamine release in nasal lavage fluids. Although ALESSANDRI et al. [16] have shown that PAF can induce histamine release from rat kidney mast cells, other authors [29] have failed to find any significant histamine-releasing activity of PAF on human skin mast cells. The difference in responsiveness may be related to the heterogeneity of rat and human mast cells. Our results suggest that nasal challenge with PAF does not provoke any significant histamine release, and are in line with the failure to find any increase in plasma histamine following bronchial challenge with PAF in allergic asthmatics [30].

As far as $\mathrm{iLTC}_{4}$ release is concerned, it has been demonstrated that PAF can induce peptide-leukotrienes release from purified eosinophils [15], and from perfused rabbit [12] or guinea-pig [13] lung. Moreover, increased urinary levels of peptide leukotrienes and thromboxane $\mathrm{A}_{2}$ have been found by TAYLOR et al. [9] in subjects undergoing bronchial stimulation with PAF. Therefore, an increase in $\mathrm{iLTC}_{4}$ levels in nasal lavage fluids could be expected, but we have not found any significant iLTC $_{4}$ release. Using the model of nasal challenge followed by nasal lavages, we could demonstrate iLTC $_{4}$ release during the early allergen-induced reaction in allergic patients $[2,18]$. Therefore, if $\mathrm{iLTC}_{4}$ is generated and released in the nose following PAF challenge, the amount should be lower than that released after antigen challenge. Other possible explanations of the failure to find iLTC $_{4}$ release may be a difference in responsiveness of bronchopulmonary cells and nasal cells to PAF stimulation, with the former generating and releasing higher amounts of iLTC $_{4}$ than the latter, and a slow release coupled with rapid metabolic degradation.

It is noteworthy that a significant increase in neutrophils was observed after insufflation of lyso-PAF both in atopic and nonatopic subjects, although the effects of this phospholipid were weaker and slower compared to PAF. Moreover, an increase in eosinophils was observed in the nasal lavages collected $3 \mathrm{~h}$ after challenge in atopic subjects, but not in nonatopic subjects. These results are in line with the findings of SАКАмото et al. [31] who have demonstrated that inhaled lyso-PAF can increase lung resistance and airway microvascular leakage in the guinea-pig, and that its effects are inhibited by a specific PAF receptor antagonist (WEB 2086). LysoPAF is generally considered to be biologically inactive in vitro; therefore, the changes in nasal cytology observed in the present study, as well as the effects on guineapig airways, could be the consequence of the acetylation and transformation of lyso-PAF into PAF in vivo in respiratory airways. In fact, it has been demonstrated that PAF can be produced by cultured bacteria supplemented with lyso-PAF [32], and PAF formation by eukariotic cells is strictly dependent on the concentration of lyso-PAF available [33]. The effects of lyso-PAF in vivo, however, are weaker than those of PAF, and, in fact, no significant release of ECP was observed after lyso-PAF administration either in atopic or in nonatopic subjects.

PAF and lyso-PAF are released during the early antigeninduced reaction in the nose of allergic patients [2, 34], and both lipids have the capacity to attract and activate neutrophils and eosinophils [6, 25-28]. Since the cytological picture of the late antigen-induced reaction in human nasal airways is characterized by local accumulation of eosinophils and neutrophils $[35,36]$, one could speculate that PAF contributes to the attraction of these cells and has a role in antigen-induced allergic inflammation in the nose. The results of this study indicate that PAF has the capacity to attract eosinophils and neutrophils and to provoke ECP release when insufflated in the human nose, and supports its possible implication in allergic rhinitis. However, further studies with PAF antagonists are needed to define the clinical relevance of PAF in allergic rhinitis more precisely.

\section{References}

1. Barnes PJ, Chung KF, Page CP. Platelet-activating factor as a mediator of allergic disease. J Allergy Clin Immunol 1988; 81: 919-934.

2. Miadonna A, Tedeschi A, Arnoux B, Sala A, Zanussi C, Benveniste J. Evidence of PAF-acether metabolic pathway activation in antigen challenge of upper respiratory airways. Am Rev Respir Dis 1989; 140: 142147.

3. Leggieri E, Tedeschi A, Lorini M, Bianco A, Miadonna A. Study of the effects of PAF-acether on human nasal airways. Allergy 1991; 46: 466-471.

4. Andersson M, Pipkorn U. The effect of platelet-activating factor on nasal hypersensitivity. Eur J Clin Pharmacol 1988; 35: 231-235. 
5. Austin CE, Foreman JC. The effect of platelet-activating factor on the responsiveness of the human nasal airway. Br J Pharmacol 1993; 110: 113-118.

6. Tedeschi A, Palumbo G, Milazzo N, Miadonna A. Nasal neutrophilia and eosinophilia induced by challenge with platelet-activating factor. J Allergy Clin Immunol 1994; 93: 526-533.

7. Cuss FM, Dixon CMS, Barnes PJ. Effect of inhaled platelet-activating factor on pulmonary function and bronchial responsiveness in man. Lancet 1986; ii: 189-192.

8. Stenton SC, Ward C, Duddridge M, Harris A, Palmer JBD, Hendrich DJ, Walters EH. The actions of GR 32191B, a thromboxane receptor antagonist, on the effects of inhaled PAF on human airways. Clin Exp Allergy 1990; 20: 311-317.

9. Taylor IK, Ward PS, Taylor GW, Dollery CT, Fuller RW. Inhaled PAF stimulates leukotriene and thromboxane $\mathrm{A}_{2}$ production in humans. J Appl Physiol 1991; 71: 1396-1402.

10. Spencer DA, Evans JM, Green SE, Piper PJ, Costello JF. Participation of the cysteinyl leukotrienes in the acute bronchoconstrictor response to inhaled plateletactivating factor in man. Thorax 1991; 46: 441-445.

11. Kidney JC, Ridge SM, Chung KF, Barnes PJ. Inhibition of platelet-activating factor-induced bronchoconstriction by the leukotriene $\mathrm{D}_{4}$ receptor antagonist ICI 204.219. Am Rev Respir 1993; 147: 215-217.

12. Voelkel NF, Worthen S, Reeves JT, Henson PM, Murphy RC. Nonimmunological production of leukotrienes induced by platelet-activating factor. Science 1982; 218: 286-288.

13. Jancar S, Theriault P, Lauziere M, Braquet P, Sirois P. PAF-induced release of spasmogens from guinea-pig lungs. Br J Pharmacol 1989; 96: 153-162.

14. Lin AH, Morton DR, Gorman RR. Acetylglyceryl ether phosphorylcholine stimulates leukotriene $\mathrm{B}_{4}$ synthesis in human polymorphonuclear leucocytes. J Clin Invest 1982; 70: 1058-1065.

15. Bruijnzeel PLB, Koenderman L, Kok PTM, Hamelink ML, Verhagen JL. Platelet-activating factor (PAF-acether) induced leukotriene $\mathrm{C}_{4}$ formation and luminol-dependent chemiluminescence of human eosinophils. Pharmacol Res Commun 1986; 18: 61-69.

16. Alessandri MG, Giovannini L, Mian M, et al. PAFinduced histamine release in the isolated perfused rat kidney. Int J Tiss Reac 1988; 1: 33-38.

17. Okuda Y, Tsuyugughi I, Yamatadani A. Histamine release from human leukocytes by platelet-activating factor. Int Arch Allergy Appl Immunol 1988; 85: 341-345.

18. Miadonna A, Tedeschi A, Leggieri E, et al. Behavior and clinical relevance of histamine and leukotrienes $\mathrm{C}_{4}$ and $\mathrm{B}_{4}$ in grass pollen-induced rhinitis. Am Rev Respir Dis 1987; 136: 357-362.

19. Randolph TG. Differentiation and enumeration of eosinophils in the counting chamber with a glycol stain; a valuable technique in appraising ACTH dosage. J Clin Lab Med 1949; 34: 1696-1701.

20. Ruff F, Saindelle A, Dutripon E, Parrot JL. Continuous automatic fluorometric evaluation of total blood histamine. Nature 1967; 214: 279-281.

21. Anderson WH, O'Donnel M, Simko BA, Welton AF. An in vivo model for measuring antigen-induced SRS-
A-mediated bronchoconstriction and plasma SRS-A levels in the guinea-pig. BrJ Pharmacol 1983; 78: 67-72.

22. Hammond MD, Abram TS, Francis HP, Jennings MA, Seager K. The development of a radioimmunoassay (RIA) for the measurement of sulphidopeptide leukotrienes in arterial plasma samples during guinea-pig anaphylaxis: comparison of results obtained by RIA, bioassay and a combination of reverse-phase HPLC and bioassay. Prostaglandins 1984; 28: 662.

23. Sautebin L, Caruso D, Galli G. Analysis of cyclooxygenase and lipoxygenase products in incubation media. Prostaglandins 1984; 27: 361-363.

24. Venge P, Roxin LE, Olsson I. Radioimmunoassay of human eosinophil cationic protein. $\mathrm{Br} J$ Haematol 1977; 37: 331-335.

25. Wardlaw AJ, Moqbel R, Cromwell O, Kay AB. Plateletactivating factor: a potent chemotactic and chemokinetic factor for human eosinophils. J Clin Invest 1986; 78 : $1701-1706$.

26. Henocq E, Vargaftig BB. Accumulation of eosinophils in response to intracutaneous PAF-acether and allergen in man. Lancet 1986; i: 1378-1379.

27. Kimani G, Tonnesen MG, Henson PM. Stimulation of eosinophil adherence to human vascular endothelial cells in vitro by platelet-activating factor. J Immunol 1988; 140: 3161-3166.

28. Kroegel C, Yukawa T, Dent G, Venge P, Chung KF, Barnes PJ. Stimulation of degranulation from human eosinophils by platelet-activating factor. J Immunol 1989; 142: 3518-3526.

29. Thomas G, Church MK. Platelet-activating factor does not release histamine from human dispersed cutaneous mast cells. Clin Exp Allergy 1990; 20: 377-382.

30. Louis R, Bury T, Corhay JL, Radermecker M. No increase in plasma histamine during PAF-induced airways obstruction in allergic asthmatics. Chest 1993; 104: 806810.

31. Sakamoto T, Elwood W, Barnes PJ, Chung KF. Effect of inhaled lyso-platelet-activating factor on airway microvascular leakage in the guinea-pig. J Appl Physiol 1993; 74: 1117-1122.

32. Denizot Y, Dassa E, Benveniste J, Thomas Y. PAFacether production by Escherichia coli. Biochem Biophys Res Commun 1989; 161: 939-943.

33. Ninio E, Mencia-Huerta JM, Heymans F, Benveniste J. Biosynthesis of platelet-activating factor (PAF-acether). I. Evidence for an acetyl-transferase activity in murine macrophages. Biochem Biophys Acta 1983; 710: 2331.

34. Meslier N, Braunstein G, Lacronique J, et al. Local cellular and humoral responses to antigenic and distilled water challenge in subjects with allergic rhinitis. Am Rev Respir Dis 1989; 137: 617-624.

35. Bascom R, Pipkorn U, Lichtenstein LM, Naclerio RM. The influx of inflammatory cells into nasal washings during the late response to antigen challenge: effect of systemic steroid pretreatment. Am Rev Respir Dis 1988; 138: 406-412.

36. Pelikan Z, Pelikan-Filipek M. Cytologic changes in the nasal secretions during the late nasal response. J Allergy Clin Immunol 1989; 83: 1068-1079. 